\title{
South Scamdlinaviam joints and Alpine/Atlantic-ridge tectonics
}

\author{
Fang Fang Zheng $\left({ }^{1}\right)$ and Adrian Eugen Scheidegger $\left({ }^{2}\right)$ \\ (1) Institutionen för Geologi och Geokemi, Stockholms Universitet, Stockholm, Sweden \\ $\left({ }^{2}\right)$ Geophysics Section, Technological University, Vienna, Austria
}

\begin{abstract}
Ficld observations and studies of the joints and dykes in an area shed light on its younger tectonic development; thus, joint orientations measured in Southern Sweden and in Norway have been statistically studied and compared regarding their tectonic significance with studies from Europe and the mid-Atlantic ridge. The present investigation indicates that the surface joint systems in Sweden agree with those in Europe; they are the result of the intracratonic stress field and the mechanical response associated with the Alpine orogeny. The stress systems in Southern Norway, on the other hand, are the result of the ongoing extensional or wrench-fault tectonism in the Atlantic crust associated with the stresses near the mid-Atlantic ridge, which act normally to the contiguous coastlines from Scandinavia to France, Portugal and North Africa.
\end{abstract}

Key words joints - neotectonics - Alps - midAtlantic ridge - Sweden - Bohus granite - Norway Scandinavia

\section{Introduction}

Joints are ubiquitously present on rocks in the form of small cracks or fissures. In outcrops they appear at first sight to present a chaotic pattern, but upon closer inspection, one generally discerns three distinct sets (systems), one of which is subhorizontal; the other two are steeply dipping and are oriented at right angles to each other and their intersections with the Earth's surface (surface joints) form a rectilinear grid (conjugate joint sets). The subhorizontal set corresponds to the rock layering; the steeply dipping (subvertical) «surface joints» have been caused by the neotectonic stress-field (Scheidegger, 1978, 1991).

Mailing address: Dr. Adrian E. Scheidegger, Institut für Geodäsie und Geophysik, Abteilung Geophysik, Technische Universität Wien, Gußhausstraße 27-29/1282, A-1040 Wien, Austria; e-mail: ascheide@luna.tuwien.ac.at
Joints might have been initiated during different tectonic events, possibly even at the time the rock was formed. However, most joints existing today seem to have been formed as young fractures during later or even the latest tectonic movement. The reasons for this are:

a) Joints are relatively small-scaled features formed as single fracture-planes during one geologically instantaneous event without displacement or with no appreciable slip along the joint planes.

b) Joints, being weak planes with high stress concentration at their ends, develop easily during fracturing and faulting.

c) Old joints or joint systems are likely to have suffered repeated tectonic stress and may have been completely obliterated. Thus, the joints which exist today are mostly young. In mountain areas, elevation/denudation rates are commonly of the order of $\mathrm{mm} / \mathrm{a}$, i.e. $\mathrm{km} / \mathrm{Ma}$ (Scheidegger, 1995); so that the presently visible surface cannot be more than a few Ma old. All surface joints must therefore be very young.

There has been some argument as to whether the steeply dipping joints are shear or tension fractures (e.g., Price, 1966; Scheidegger, 1978, 
1991; Segall and Pollard, 1983a,b; Hancock and Engelder, 1991): in theory, there exist two possibilities for their formation: 1) if these joints are shearing joints, they appear at the surface as a grid of «conjugate» joint sets; according to Mohr's (1928) theory of fracture their bisectrices are the principal tectonic stress directions, the maximum compression $\left(P=\sigma_{3}\right)$ being enclosed in the smaller quadrant. 2) If «tension» (i.e. pressure-relief $T=\sigma_{1}$; there surely cannot exist an absolute tension anywhere below ground on account of the overburden; except under artificial conditions such as occur during hydrafracturing in wells) is responsible for the joint formation, the joint planes are parallel to the maximum compressional stress $\left(P=\sigma_{3}\right)$ direction. Dilatation determines joint initiation and propagation (Segall and Pollard, 1983a,b). Tensional fracture, however, can never easily produce conjugate joint sets (there exists only one maximum compression direction at a given location in any stress field), without a rather complicated turning or «swap» of the principal stresses during the formation of the system (Caputo, 1995); thus this possibility has to be ruled out for most surface joint sets; conjugate joint sets in the uppermost crust must be due to shearing stresses caused by the regional neotectonic stress field (Scheidegger, 1978).

The regularities mentioned are not absolute; they have therefore to be studied statistically. This can be done non-parametrically by the inspection of a joint-pole density diagram: then, the «mean» directions of the joint sets are indicated by the pole-density maxima which can be picked optically: these maxima present the «mean» directions of the corresponding jointsets. For steeply dipping joints, a strike-rose may be sufficient and afford a better visualization.

A more sophisticated analysis is achieved by a numerical statistical method (henceforth referred to as «standard method») as described by Kohlbeck and Scheidegger (1977, 1985). The latter is based on the assumption that the jointpoles belonging to one set (as defined above) correspond to a Dimroth (1963); Watson (1970) distribution which, on a sphere, is the equivalent of a Gaussian distribution on a line; a Dimroth-Watson distribution is determined by 4 parameters. If $\mathrm{x}$ such distributions are superposed on a sphere, their integral must be equal to 1 ; for this reason, one does not need $4 \mathrm{x}$ parameters to determine $x$ distributions, but only $4 x-1$. Usually, only the two subvertical sets are of interest, because they alone correlate with the tectonics of the area. Two distributions require for their determination $4 \times 2-1=7$ parameters. Generally, every physically measured value has to be supported by 3 individual measurements; thus the determination of the directions of two sets of joints at an outcrop requires $3 \times 7=21$ joint orientation measurements. This may appear as a small number, but Kohlbeck and Scheidegger (1985) have given an explicit verification of this statement: if two individual sets exist at all at an outcrop, 21 measurements are indeed sufficient; taking more measurements increases the accuracy of the result only insignificantly.

Once the orientations of the principal joint sets have been determined, it is possible to determine therefrom the orientation of the principal stress directions of the neotectonic stress field that has caused them (Kohlbeck and Scheidegger, 1977, 1985): According to earlier remarks (cf. Mohr, 1928) these are the bisectrices of the two subvertical joint sets; the smaller angle contains the maximum compression $(P)$, the larger angle the minimum compression $(T)$; however, if the intersection angle between conjugate joint sets is close to $90^{\circ}$, it is not possible to identify the smaller angle with certainty.

Thus, joint orientation measurements allow one to determine the («mean») directions of joint sets, and to investigate whether these directions are related to other geomorphologically important directions. If a coincidence is present, then the corresponding geomorphological features are, like the joints, most probably neo-tectonically predesigned.

\section{Regional geology}

\subsection{Bohus granite, Southern Sweden}

The well-exposed late Precambrian Bohus granite (age $\mathrm{ca}$. $920 \mathrm{Ma}$ ) on the west coast of Sweden (see sketch map in fig. 1 , inset) is a 


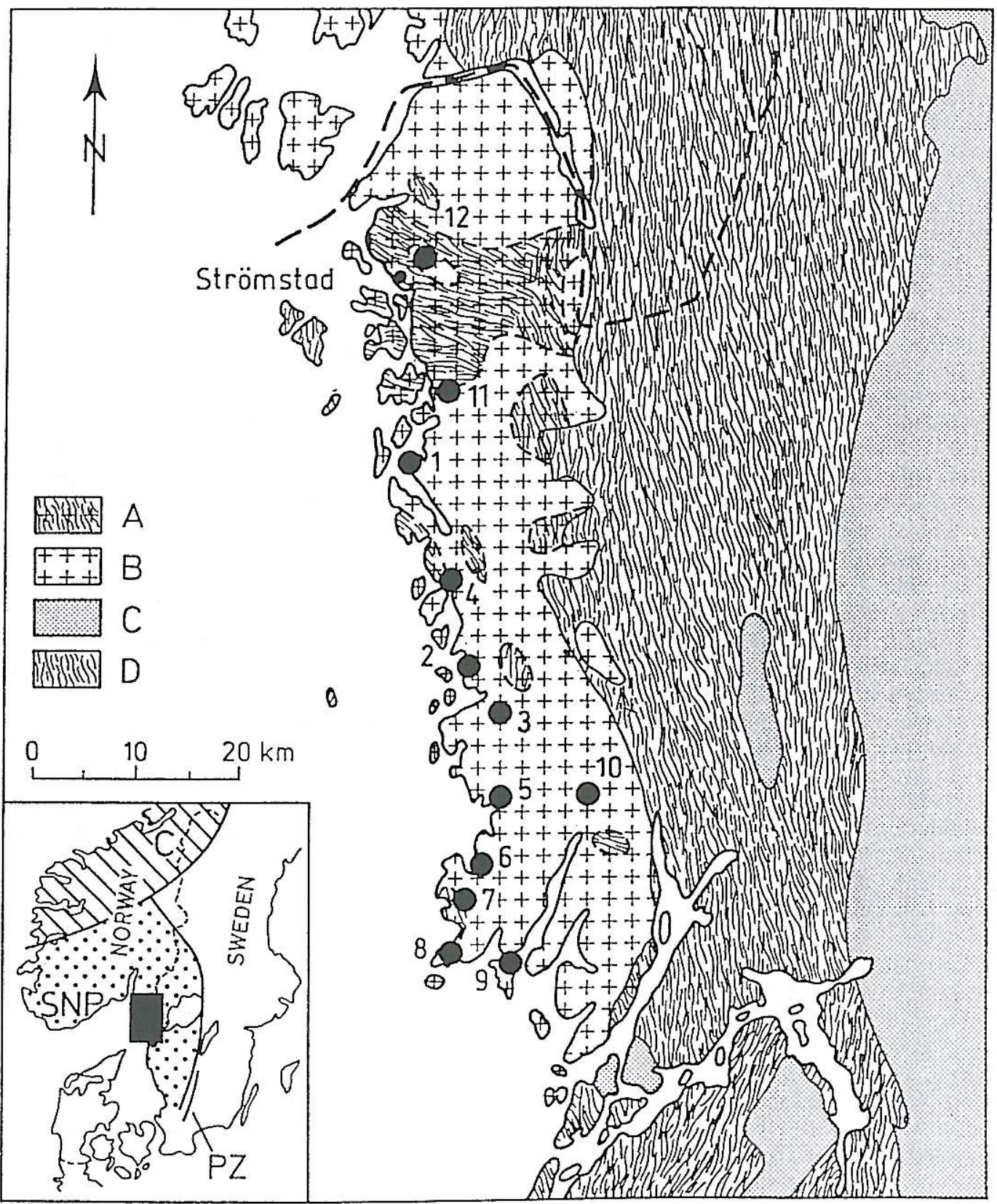

Fig. 1. Sketch map of the Bohuslän area under investigation: the Bohus granite is surrounded by the Stora LeMarstrand Group of gneisses (modified from Eliasson and Schöberg, 1991). A = Stora Le-Marstrand Group, mainly gneissic ( $c a .1758 \mathrm{Ma}) ; \mathrm{B}=$ Bohus granite $(c a .920 \mathrm{Ma}) ; \mathrm{C}=$ tonalitic-granodioritic orthogneisses; $\mathrm{D}=$ Bohus granite rich in Stora Le-Marstrand rock pieces. Black dots (1-12) indicate the locations of joint orientation measurements. 
relatively unmetamorphosed and little-deformed intrusive body (Asklund, 1947), the host rock belonging to a mainly gneissic complex (StoraLe Marstrand Group, cf. fig. 1) dating from $c a$. $1750 \mathrm{Ma}$ (Åhäll and Daly, 1989). Superimposition of structural and fractural lineaments of the Bohus granite developed in different tectonic movements during the last $900 \mathrm{Ma}$. These tectonic lineament patterns developed during the repeated influence of orogenic events of Grenvillian-Sveconorwegian, Caledonian, Variscan, as well as Alpine ages and of subsequent nonorogenic events. The Sveconorwegian Province including SW Sweden and S Norway was strongly reworked and deformed by the GrenvillianSveconorwegian tectonism that occurred prior to the formation of the Bohus granite approximately 1259 Ma ago (Falkum and Petersen, 1980; Welin et al., 1982; Gaál and Gorbatschev, 1987). Understanding the Grenvillian-Sveconorwegian tectonism may help to reveal the origin of the Bohus granite and of the fundamental architecture of granite structures and post-granite fractures (Zheng, 1996). The NW part of the granite is likely to have suffered from Caledonian thrusting and deformation. Further, the Bohus granite area was strongly influenced by the late Variscan events of the Oslo-Skagerrak rift/ graben system, due to Permian intrusions of dykes and dyke swarms into the granite along the fault-lines parallel to the coast. Furthermore, during post-Variscan times, Alpine tectonic movements might have left faults, joints and fabric structures superimposed on the granite and dykes.

Two dominant N-S striking faults, viz. the Koster-Väderörna (Kattegat) fracture system (Flodén, 1973) and the Bullare fault zone delimit the Bohus granite as an elongated body (Zheng, 1996). The major faults of the granite strike NNW-NW in the northern-middle granite area, and NNE-NE in the southern area (Asklund, 1947). Roughly N-S coast-parallel and conjugate E-W directions are well developed.

Further afield, the study area is surrounded by prominent tectonic fault zones (fig. 2a,b; Zheng, 1996), forming a regular network: the Caledonian front is located not far northwest of Oslo (trending NE in the S); the Skagerrak-Oslo graben striking also NE, like the S-part of the Protogine zone and the Gotland-Oland zone. The conjugate direction is represented by the Tornquist fault complex («Tornquist-Sorgenfrei zone») which extends in a northwesterly direction across Scania, Denmark and the outer Skagerrak.

\subsection{Oslo-Telemarken area, Southern Norway}

Southern Norway lies mainly on the crystalline Fennoscandian basement (Proterozoic metasediments). The part of the basement lying to the west (i.e. outside) of the Oslo region consists mainly of gneisses, granites and dykes, whose isotopic ages range from $\mathrm{ca}$. $1760 \mathrm{Ma}$ to ca. $830 \mathrm{Ma}$. In addition, these basement rocks were, in part, strongly folded during the Caledonian Orogeny. Around Oslo (Ramberg and Larsen, 1978) there is a graben indicated by Cambrian-Silurian sedimentary rocks as well as by many late Variscan intrusions and extrusions. The graben began by being formed as a series of aulacogens from Cambrian to Silurian times. It was filled in early Permian times at the climax of the taphrogenesis by limestones and volcanic breccias which were later deformed during a prolonged period from late Paleozoic to Mesozoic times (Ramberg and Larsen, 1978, pp. 5557). Today's topography, which shows mountains $2000 \mathrm{~m} \mathrm{high}$, is, however, the result of recent (post-Cretaceous) crustal movements which are connected with the Alpine orogenesis. The isostatic uplift after the last ice age is insignificant in this connection. The North-Sea oil is found in shelf-sediments. The basement dips down into a eugeosyncline which is filled with Paleozoic to recent sediments.

\subsection{Bergen area, Southwestern Norway}

The base of the Norwegian hills near Bergen (Sturt and Thon, 1978) consists of Precambrian rocks, subject to Caledonian metamorphism; the strongest diastrophism in this connection occurred in Scandinavia in the Silurian time, but earlier (e.g., Cambrio-Ordovician mica-schists near Halljem) and later (Permian volcanites) 


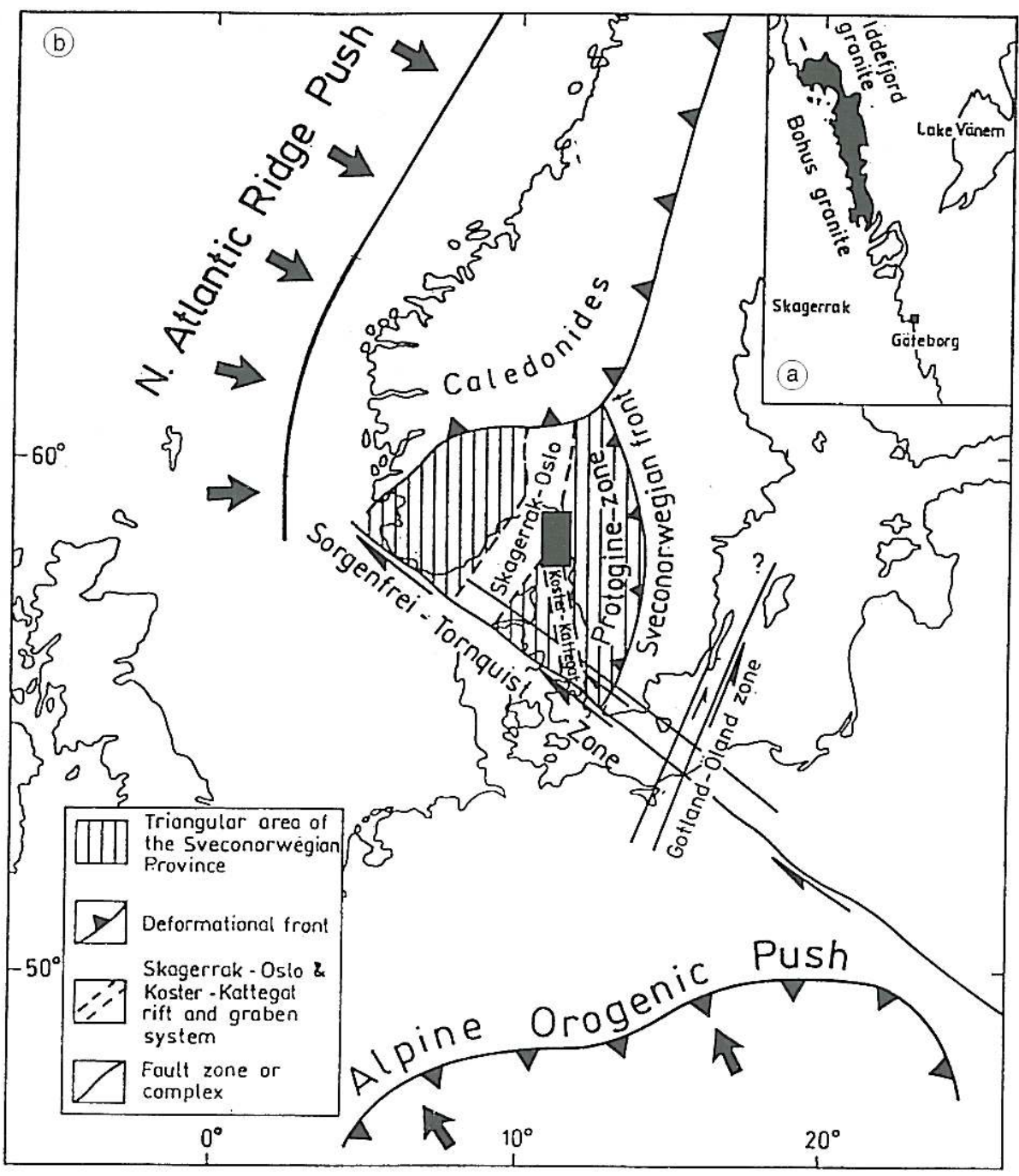

Fig. 2a,b. a) Black: the Bohus granite on the west coast of Sweden and the adjoining parts of Norway (Iddefiord granite), according to Welin and Gorbatschev (1978). b) The «Alpine Orogenic push» from the (south-)southzast and the "North Atlantic ridge push" acting at right angles to the Norwegian coastline, i.e. from the west $<62^{\circ} \mathrm{N}$ latitude) and north-west $\left(>62^{\circ} \mathrm{N}\right.$ latitude), in relation to the Sorgenfrei-Tornquist, Skagerrak-Oslo, Jrotogine and Gotland-Oland disturbance zones.

thases have also been found. The actual topogaphy, however (in particular the elevation of he $2000 \mathrm{~m}$ high mountains separating Norway rom Sweden), is of post-Cretaceous origin, :onnected with the Alpine orogenesis (Sturt and [hon, 1978).

\section{Joint orientation measurements}

\subsection{Bohus granite}

Field observations and joint orientation measurements were made in the Bohus granite area 
at natural outcrops, quarries and road cuts along a N-S distance of about $80 \mathrm{~km}$. Brittle joints with roughly vertical planes were selected for measurement. The individual joints are commonly $1-10 \mathrm{~m}$ in length, but some may be longer, up to $100 \mathrm{~m}$, and some may be shorter than $1 \mathrm{~m}$. The widths of individual joints are generally less than a couple of millimetres. By estimation, the apparent transverse frequency of the joints is commonly only a couple per metre Almost all joints with fresh surfaces are void of fillings and without mineral alteration. Smooth joint surfaces are apparently more common than rough or striated ones.

Each locality was approximately $1-5 \mathrm{~km}$ in size and each site may cover some tens of metres. The distance between sites may vary from a few hundred metres to a couple of kilometres. Altogether, about 1000 joint orientations were measured at 12 localities (black dots in fig. 1 and table I). At each locality 2-4 sites were selected, and 21-36 measurements were taken at each site. The data were processed using the standard method. The results for the individual areas are listed in table I.

When all locations in the Bohuslän are combined, two dominant joint populations striking ESE (azimuth $\mathrm{N}>\mathrm{E}$ of strike direction $107^{\circ}$ ) and NNE (azimuth of strike direction $\mathrm{N} 23^{\circ} \mathrm{E}$ ) are found (see table I and fig. 3a,b). These are also approximately the trends of the GotlandOrland and Skagerrak zones (NNE) and of the conjugate Sorgenfrei-Tornquist zone (SW). The maximum compressive stress $(P)$ corresponding to the two conjugate joint sets (with an angle of $84^{\circ}$ between them) has an orientation-azimuth of approximately $\mathrm{N} 155^{\circ} \mathrm{E}$ and the minimum stress $(T)$ an azimuth of approximately $\mathrm{N} 65^{\circ} \mathrm{E}$. In addition, another joint set striking with a direction of $c a$. $N 65^{\circ} \mathrm{E}$ is weakly, but distinctly present; it could have been created by some single tension. The values from the indi-
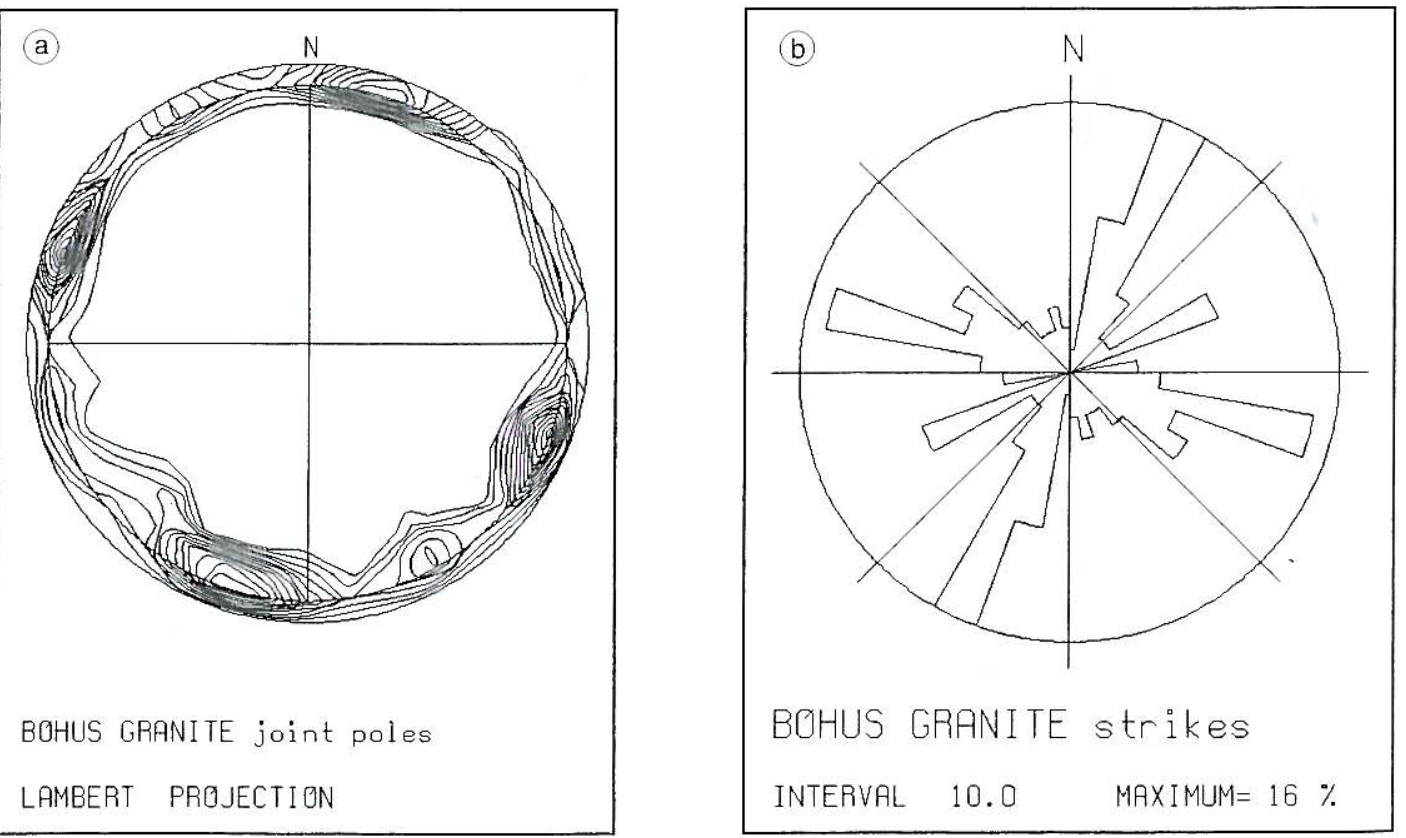

Fig. 3a,b. a) Pole-density diagram and (b) strike-rose diagram based on 789 joint measurements in the Bohus granite showing preferential strikes at $\mathrm{N} 23^{\circ} \mathrm{E}$ and at $\mathrm{N} 107^{\circ} \mathrm{E}$, implying a maximum horizontal compression oriented approximately $\mathrm{N} 155^{\circ} \mathrm{E}$. 
Table I. Strike/trend directions of joints, valleys, lineaments and fiords in the study areas.

\begin{tabular}{|c|c|c|c|c|c|c|}
\hline \multirow{2}{*}{$\begin{array}{r}\text { Bohus granite } \\
\text { Localities }\end{array}$} & \multirow[b]{2}{*}{ No. } & \multicolumn{5}{|c|}{ Strike directions of joints (outcrops) } \\
\hline & & $\operatorname{Max} 1$ & $\operatorname{Max} 2$ & Angle & $P$ & $T$ \\
\hline 1 - Raftötången & 43 & $118 \pm 04$ & $18 \pm 13$ & 80 & 156 & 68 \\
\hline 2 - Fjällbacka & 76 & $124 \pm 08$ & $37 \pm 16$ & 87 & 81 & 170 \\
\hline 3 - Bergsgården & 86 & $131 \pm 20$ & $34 \pm 07$ & 83 & 172 & 82 \\
\hline 4-Grebbestad & 69 & $101 \pm 05$ & $32 \pm 08$ & 68 & 68 & 157 \\
\hline 5 - Bottnafjorden & 102 & $119 \pm 30$ & $40 \pm 19$ & 77 & 80 & 169 \\
\hline 6 - Ulebergshamn & 70 & $168 \pm 23$ & $84 \pm 13$ & 84 & 126 & 36 \\
\hline 7 - Sotekanalen & 72 & $100 \pm 15$ & $18 \pm 05$ & 80 & 60 & 150 \\
\hline 8 - Smögen & 84 & $110 \pm 01$ & $23 \pm 05$ & 87 & 67 & 156 \\
\hline 9 - Malmön & 93 & $112 \pm 10$ & $17 \pm 11$ & 86 & 154 & 64 \\
\hline $10-\AA ̊ ̊ 口 b y f j o r d e n$ & 84 & $102 \pm 12$ & $15 \pm 20$ & 87 & 59 & 149 \\
\hline 11 - Hessland & 87 & $164 \pm 25$ & $61 \pm 08$ & 79 & 24 & 112 \\
\hline 12 - Stene & 93 & $144 \pm 50$ & $64+07$ & 80 & 104 & 14 \\
\hline All joints & 789 & $107 \pm 00$ & $23 \pm 01$ & 84 & 155 & 65 \\
\hline \multicolumn{2}{|l|}{ Norway-south } & \multicolumn{5}{|c|}{ Strike/trend directions of joints/valleys and lineaments } \\
\hline Localities & No. & Max 1 & $\operatorname{Max} 2$ & Angle & $P$ & $T$ \\
\hline A - Elgsjö & 12 & $131 \pm 10$ & $43 \pm 12$ & 89 & 87 & 176 \\
\hline B - Venemo D. & 2 & $95 \pm$ & $85 \pm$ & 80 & 136 & 45 \\
\hline C - Björnevatn & 64 & $134 \pm 10$ & $59 \pm 26$ & 78 & 96 & 7 \\
\hline E- Oslo-Kungs P. & 21 & $170 \pm 15$ & $78 \pm 54$ & 90 & 34 & 123 \\
\hline F - Oslo-Fornebu & 63 & $146 \pm 07$ & $61 \pm 10$ & 84 & 104 & 13 \\
\hline N - Dalen & 88 & $173 \pm 10$ & $114 \pm 05$ & 60 & 145 & 53 \\
\hline All joints & 209 & $136 \pm 10$ & $55 \pm 09$ & 82 & 95 & 6 \\
\hline Vallcys & 78 & $140 \pm 05$ & $(02 \pm 02)$ & 41 & & \\
\hline Lineaments & 73 & $149 \pm 01$ & $48 \pm 07$ & 79 & 8 & 98 \\
\hline
\end{tabular}

\section{Norway-Bergen region}

\begin{tabular}{lrrrrrr}
\cline { 3 - 6 } \multicolumn{1}{c}{ Localities } & No. & Max 1 & Max 2 & Angle & $P$ & \multicolumn{1}{c}{$T$} \\
\hline 1- Bergen town & 65 & $145 \pm 26$ & $46 \pm 10$ & 81 & 4 & 96 \\
2 - Nesttun & 62 & $141 \pm 11$ & $41 \pm 08$ & 81 & 1 & 91 \\
3 - Hallhjem & 64 & $159 \pm 00$ & $51 \pm 19$ & 74 & 15 & 105 \\
4 - Kokstad & 64 & $178 \pm 09$ & $78 \pm 12$ & 81 & 38 & 128 \\
5 - Hellesöy & 63 & $139 \pm 11$ & $41 \pm 11$ & 83 & 0 & 90 \\
6- Torsvik & 64 & $162 \pm 08$ & $81 \pm 03$ & 82 & 122 & 32 \\
7 -Fjell & 63 & $99 \pm 12$ & $4 \pm 08$ & 84 & 141 & 52 \\
8 - Klokkarvik & 64 & $117 \pm 09$ & $16 \pm 11$ & 78 & 157 & 67 \\
All joints & 509 & $147 \pm 09$ & $47 \pm 04$ & 80 & 7 & 97 \\
Fiords & 51 & $151 \pm 06$ & $51 \pm 11$ & 81 & 11 & 101 \\
$P$-Earthquake & 18 & & & & 96 & \\
\hline
\end{tabular}


Sw Sweden (Bohus joints)

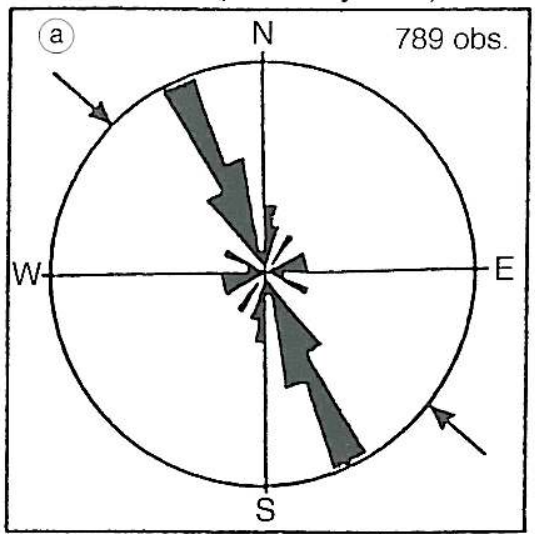

S Sweden (earthquake)

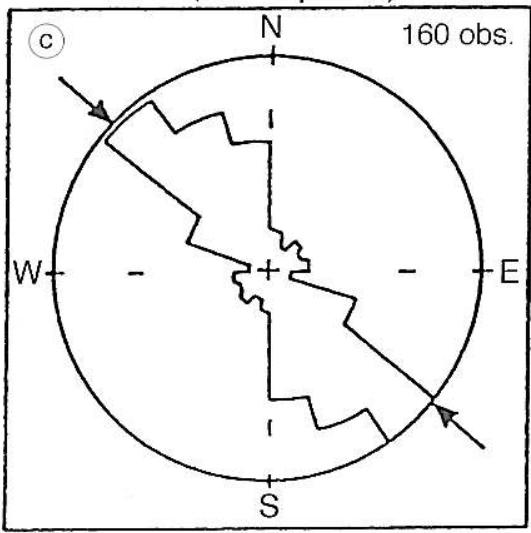

In Situ S Sweden

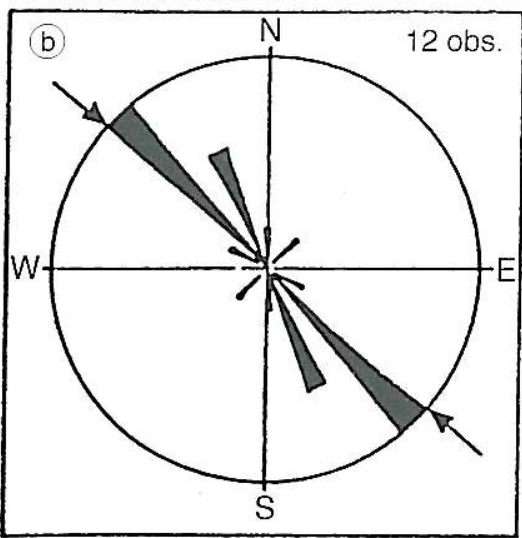

\section{Scandinavia}

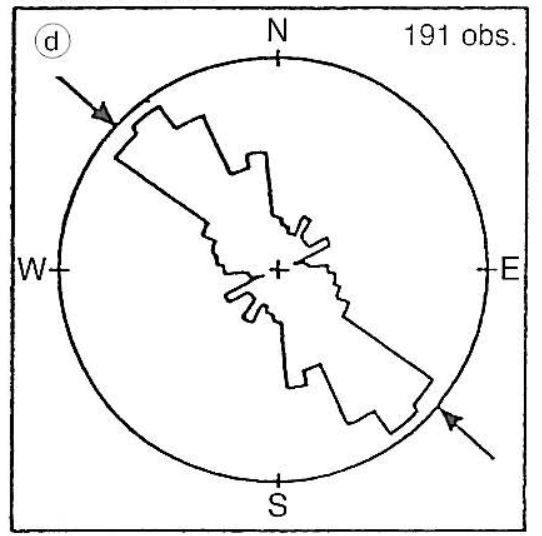

Fig. 4a-d. a) Rose diagram for the $P$-directions of individual Bohus granite outcrops; b) Rose diagram of the main horizontal compression directions resulting from absolute rock stress measurements in the Bohus granite with a maximum at $\mathrm{N} 156^{\circ} \mathrm{E}$ according to Hast (1974); c) Rose diagram of $P$-directions found in fault plane solutions of S-Swedish regional earthquakes according to Slunga (1981) and Slunga et al. (1984); d) Rose diagram of $P$-axes found by Gregersen et al. (1991) in fault plane solutions of earthquakes in Scandinavia (mostly Sweden).

vidual locations scatter somewhat around the above directions, but show generally the same pattern (fig. 4a).

The NNW $\left(\mathrm{N} 155^{\circ} \mathrm{E}\right)$ maximum-pressure direction in the Bohus area (fig. 4a) agrees approximately with:

1) The continental-European neotectonic stress state with maximum pressure directed NNW-SSE and/or NW-SE as determined from joint orientations (Scheidegger, 1993, 1995).
2) The approximately (N)NW (156 $)$ maximum compressional stress direction in Rixö (Bohus granite) and also in Southern Sweden (fig. 4b) determined by absolute in-situ rock stress measurements (Hast, 1974).

3) The consistent northwest direction of the maximum pressure found from earthquake fault plane solutions in Southern Sweden found by Slunga and others (Slunga, 1981; Slunga et al.,1984; fig. 4c). 
4) The approximately NW directed maximum pressure found from seismic studies in all Scandinavia (mostly Sweden, fig. 4d) by Gregersen et al. (1991).

5) The results shown in the World Stress Map of Zoback (1992).

6) The stress directions given in the European stress map (Müller et al., 1992), which shows that the stress regime of the Southern Bohuslän area as well as of the whole European continent has a main NNW-SSE and/or NW-SE compression.

\subsection{Oslo-Telemarken area}

Joint orientation measurements were made in the S of Norway around Oslo and near the airport of Fornebu as well as during a geological excursion to Telemarken. The measurements were taken at the outcrops $\mathrm{A}, \mathrm{B}, \mathrm{C}, \mathrm{E}$ and $\mathrm{F}$ shown in fig. 5 . In addition, joint orientation measurements from the limestone quarry at Dalen (Locus $\mathrm{N}$ in fig. 5) were made available to the writers by the management of the quarry. The data were evaluated according to the stand-

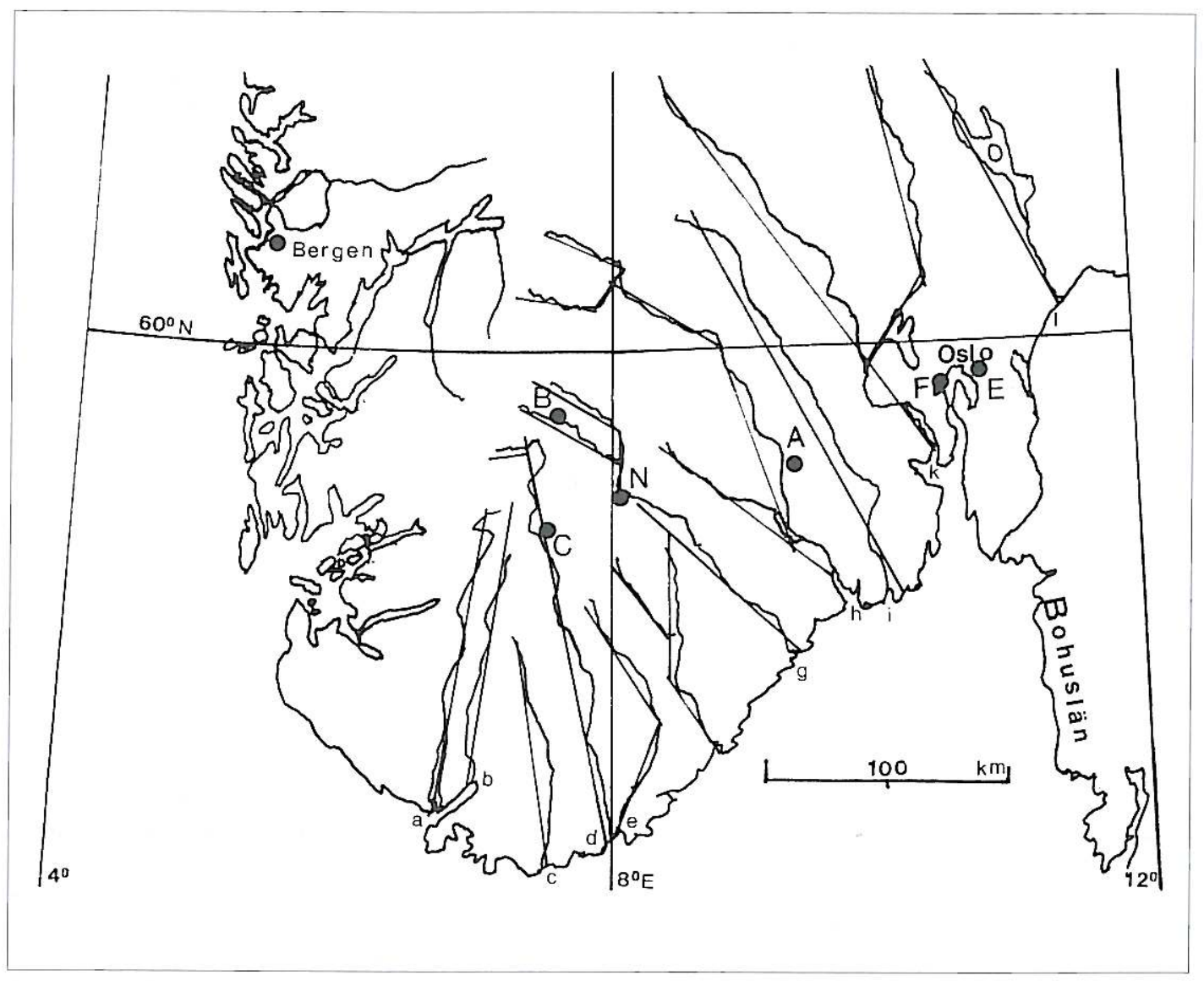

Fig. 5. Sketch map of the Southern Norwegian areas under investigation. The locations of joint orientation measurements near Oslo and in Telemark are shown by the letters A, B, C, E, F, and N; the approximations to the river trends are shown by straight lines. 


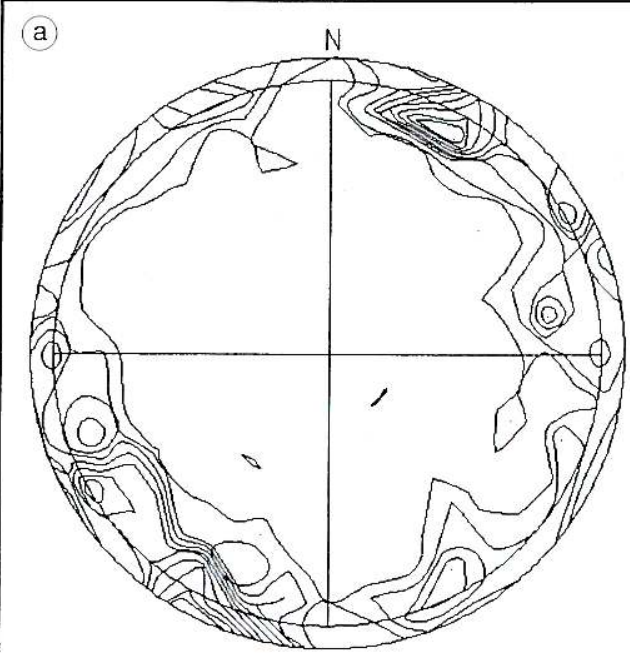

NORWAY-SOUTH JUINT-poles

LAMBERT PROJECTION

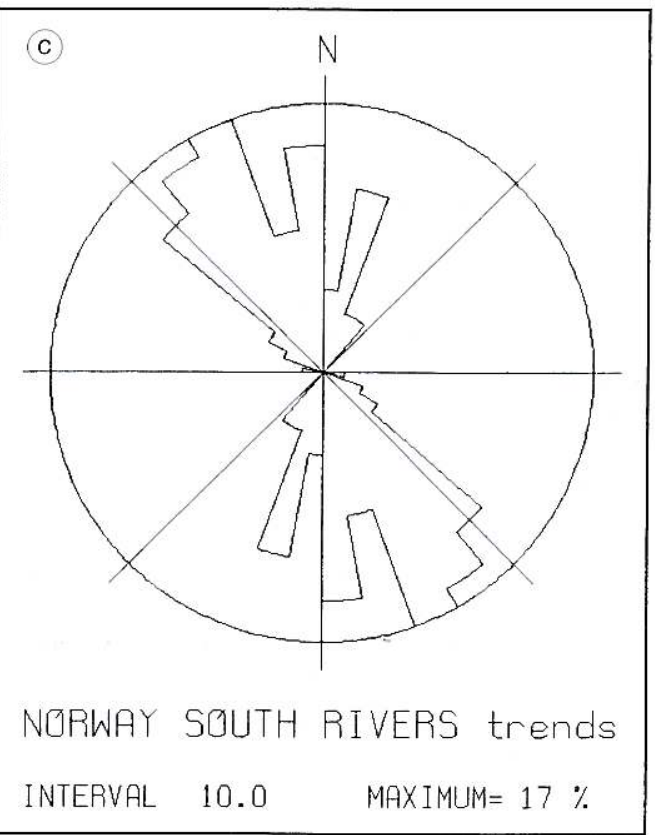

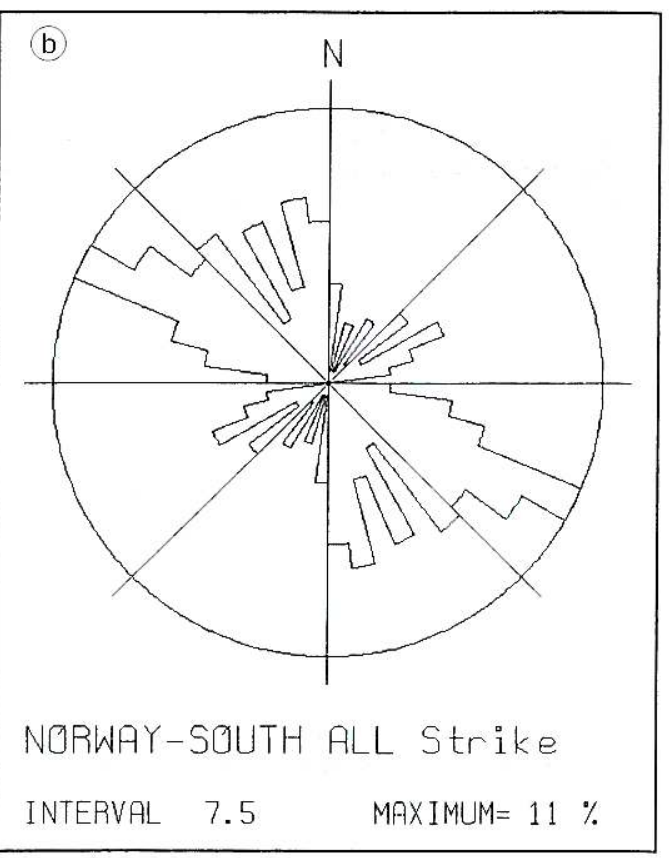

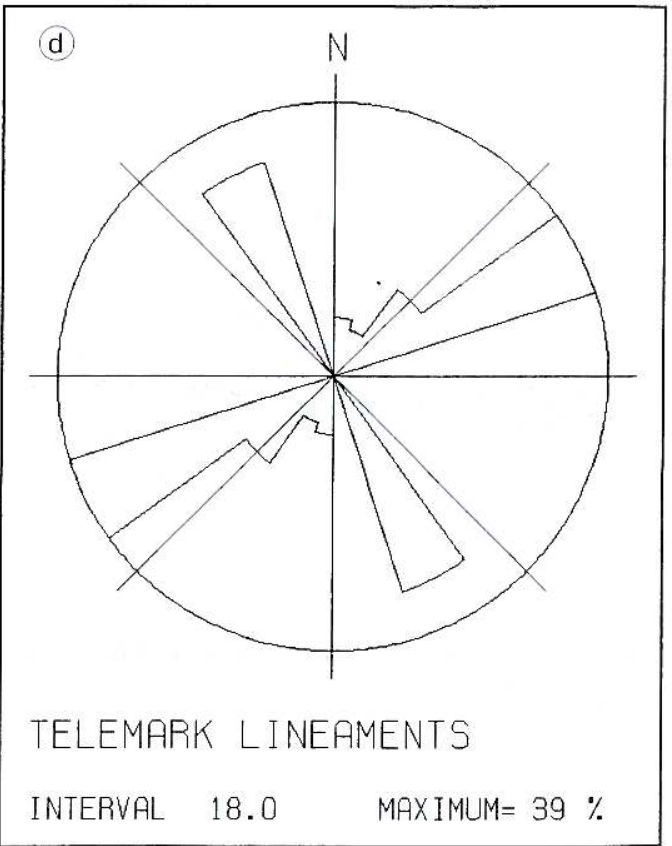

Fig. 6a-d. Oslo-Telemark region: a) pole-density diagram and (b) strike-rose of the joints; c) trend rose of the river directions; d) trend rose of the lineaments investigated by Ramberg and Larsen (1978). 
ard method. Table I contains a summary of the results.

The joints around Oslo and in Telemark (locations of measurements see fig. 5) are mainly striking (fig. 6a,b and table I) NW-SE (N55 ${ }^{\circ} \mathrm{E}$ ) and NE-SW $\left(\mathrm{N} 136^{\circ} \mathrm{E}\right)$. Accordingly, the principal stress directions are trending $\mathrm{N}-\mathrm{S}\left(\mathrm{N} 06^{\circ} \mathrm{E}\right)$ and $\mathrm{E}-\mathrm{W}\left(\mathrm{N} 95^{\circ} \mathrm{E}\right)$, somewhat different from those in $\mathrm{S}$ Sweden.

The pattern is confirmed in the orientations of the river valleys. We have approximated the trends of the rivers in S Norway by straight lines (fig. 5) and evaluated these statistically like joints by the standard method. The trend-rose is shown in fig. 6c; statistically, there are two prevalent trends ( $c f$. table I), one of which is approximately $\mathrm{N} 140^{\circ} \mathrm{E}$ and thus corresponds to one of the joint sets. The other is $\mathrm{N}-\mathrm{S}\left(\mathrm{NO} 2^{\circ} \mathrm{E}\right)$ and corresponds to the various «kink-directions» in the rivers.

A further coincidence of the joint-strikes and (preferred) river trends is observed with regard to the «lineaments» (unspecified fractures) which Ramberg and Larsen (1978, p. 56) analysed in the Oslo-Telemark region. Their results were digitized and evaluated by us; we obtained preferred lineament-trend directions $N 48^{\circ} \mathrm{E}$ and N $149^{\circ} \mathrm{E}$ (fig. $6 \mathrm{~d}$ and table I), thus $P=\mathrm{N} 08^{\circ} \mathrm{E}$ and $T=\mathrm{N} 98^{\circ} \mathrm{E}$. Thus, one observes indeed very close correlations between the joints, rivers, in-situ stress measurements and Ramberg's lineaments. The fact that the lineaments agree with the joint strikes, indicates that the former are not old features, but are, like the joints, likely to be predesigned by the neotectonic stress field.

\subsection{Western Norway (latitude $<62^{\circ} \mathrm{N}$ )}

Joint orientation measurements were made in the W-Norwegian (Bergen) area (Storetvedt and Scheidegger, 1992). The locations investigated are shown by dots and numbers from 1 (A-C) to $8(\mathrm{~A}-\mathrm{C})$ in fig. 7. The data were evaluated according to the standard method. The results are summarized in table I.

The situation around W Norway (Bergen) is similar to that in S Norway: the preferred joint strikes are again (table I and fig. 8a,b) NW-SE
$\left(\mathrm{N} 47^{\circ} \mathrm{E}\right)$ and $\mathrm{NE}-\mathrm{SW}\left(\mathrm{N} 147^{\circ} \mathrm{E}\right)$, with the principal stress directions essentially $\mathrm{N}-\mathrm{S}\left(\mathrm{N} 07^{\circ} \mathrm{E}\right)$ and $\mathrm{E}-\mathrm{W}\left(\mathrm{N} 97^{\circ} \mathrm{E}\right)$. This agrees also with the trends of the fiords: we have approximated the «medians» of the latter by straight lines (sce fig. 7) and analysed them by the standard method: There are two preferred trends (fig. $8 \mathrm{c}$ and table I), viz. $\mathrm{N} 51^{\circ} \mathrm{E}$ and $\mathrm{N} 141^{\circ} \mathrm{E}$ implying principal stress directions of $\mathrm{N} 11^{\circ} \mathrm{E}$ and $\mathrm{N} 101^{\circ} \mathrm{E}$. If it is assumed that in these results $P$ and $T$ are reversed (as explained in the section on evaluations in this paper), this agrees with the $P$-directions $\left(\mathrm{N} 96^{\circ} \mathrm{E}\right)$ from earthquake fault plane solutions in the area (Bungum et al., 1991; cf. fig. 9 a). In addition, in-situ stress measurements from all of Norway (fig. 9b) also show prominent $P$-maxima in the E-W $\left(\mathrm{N} 86^{\circ} \mathrm{E}\right)$ and $\mathrm{N}-\mathrm{S}$ (N07 ${ }^{\circ} \mathrm{E}$ ) directions (Bungum et al., 1991). The usual European NW-SE (N142 $\left.{ }^{\circ} \mathrm{E}\right)$ direction is also present. The latter seems to occur again in Northern Norway and in inland areas.

\section{Interpretation}

\subsection{General remarks}

A comparison of the joint directions from Bohuslän and from Norway shows at once that there is a discrepancy between the two. Whereas the Bohus joint directions agree closely with those from continental Europe (Scheidegger, 1993), those in Southern Norway including Bergen $\left(<62^{\circ} \mathrm{N}\right.$ latitude) are turned by approximately $45^{\circ}$ which corresponds to the «NorthSea» joint-orientations (see Storetvedt and Scheidegger, 1992).

The constant results of the maximum compression stresses characterized by NW and NNW directions in Southern Sweden and mid-Europe north of the Alps correspond to an Alpine orogenic push operative from a SW-direction for the last $40 \mathrm{Ma}$ or so. The N-S and E-W directions in $\mathrm{S}$ Norwegian areas might be caused by a 'ridge push' from the North Atlantic Ridge (Artyushkov, 1973; Zoback et al., 1986; Stephansson, 1988; Stephansson et al., 1991), which (according to general features of stresspotentials) is deflected at a discontinuity such as a coast-line into a trend normal to the latter 


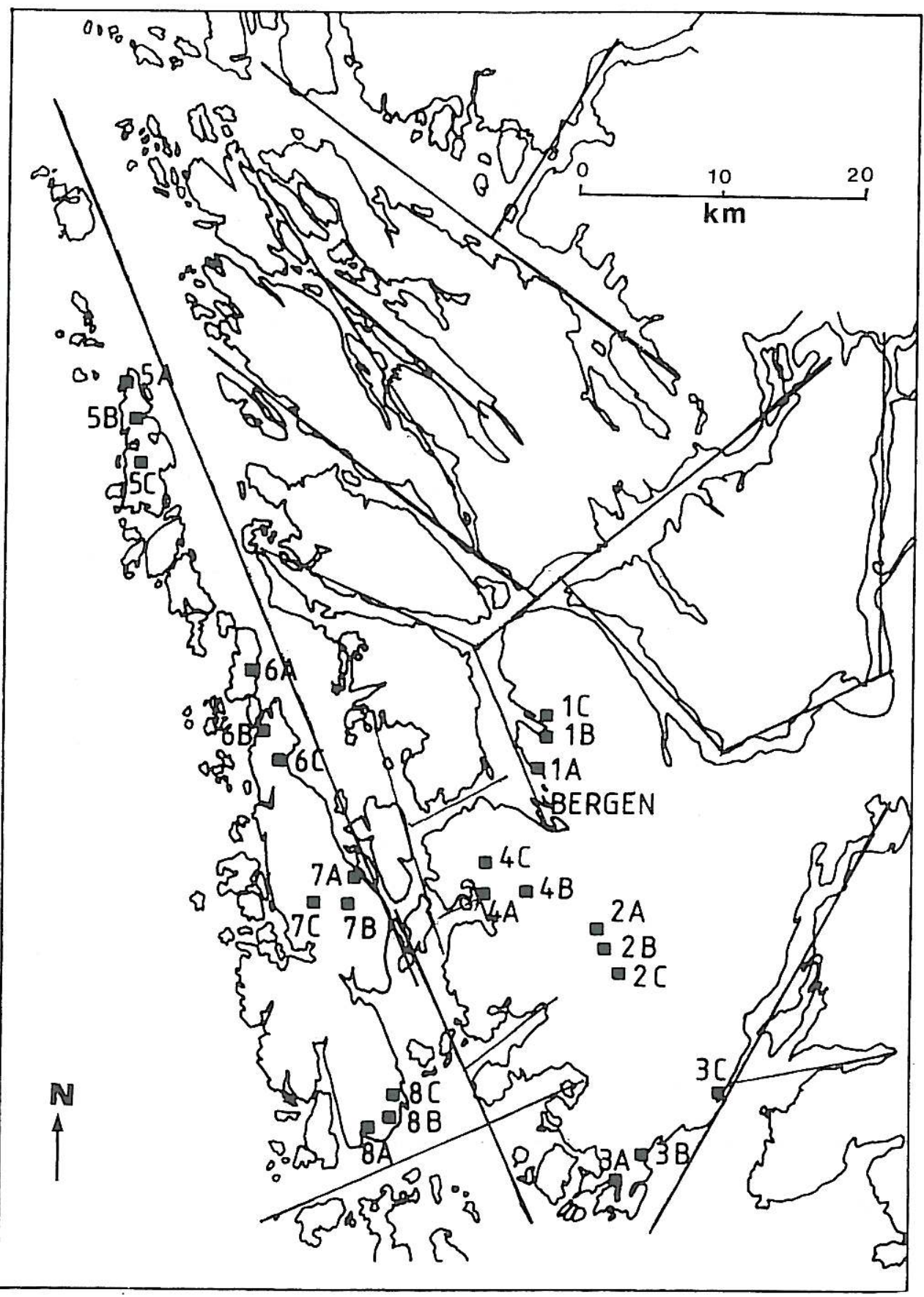

Fig. 7. Locations of joint orientation measurements in the Bergen area (1A,B,C to 8A,B,C); the black median lines of the fiords were used for the evaluations of the «fiord trends». 

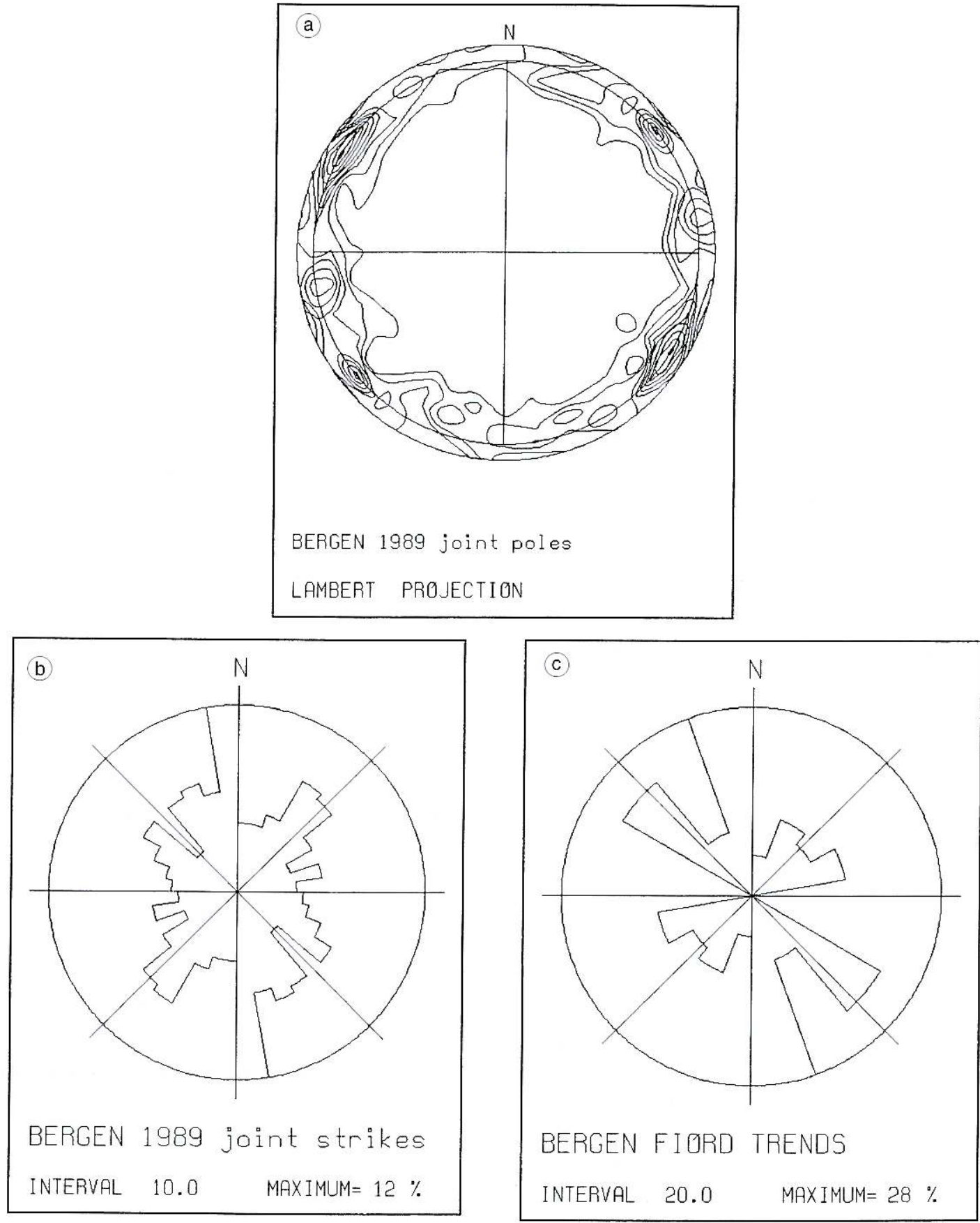

Fig. 8a-c. Western Norway: a) pole density diagram and (b) strike-rose diagram of the joints around Bergen; c) trend-rose of the fiords near Bergen. 

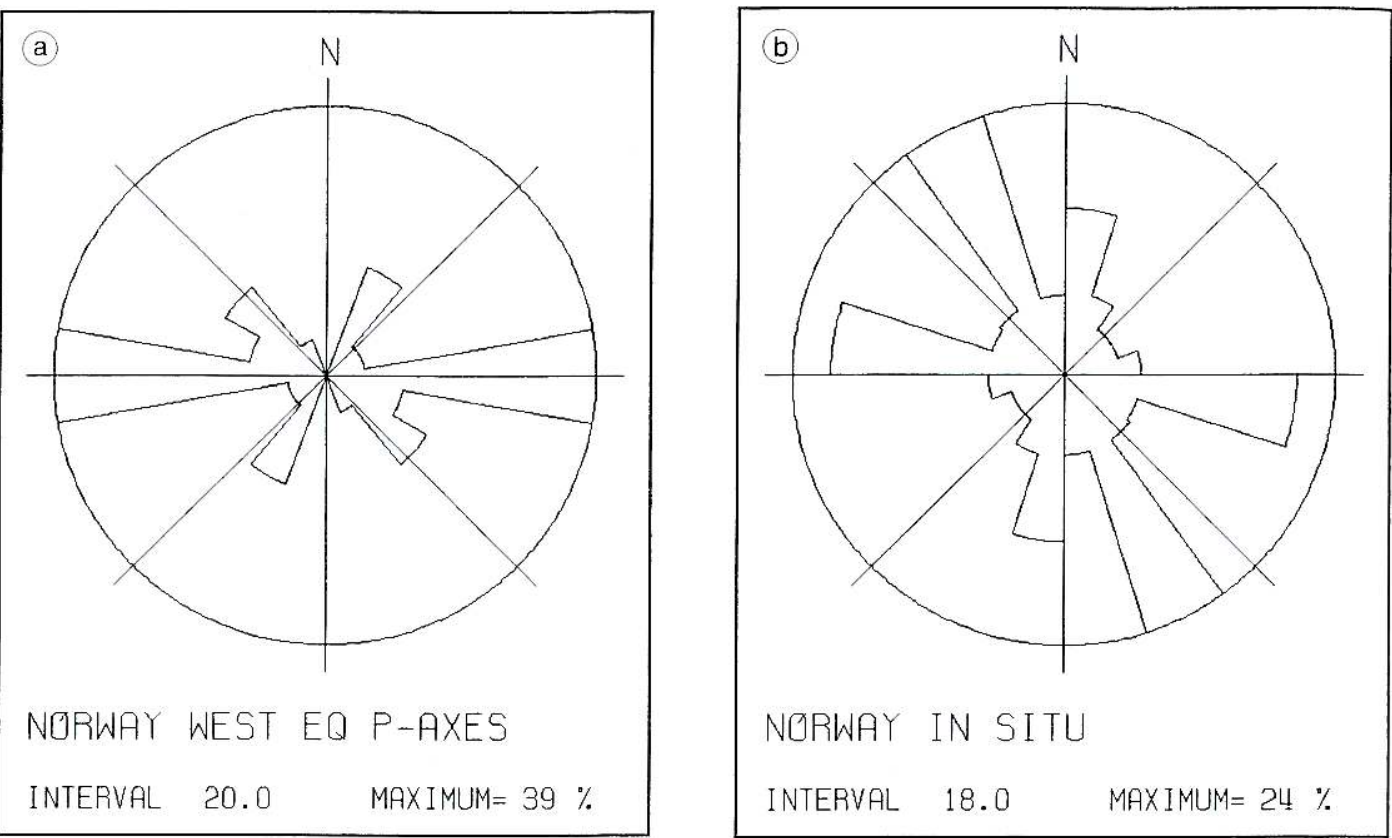

Fig. 9a,b. a) Trend-rose of the $P$-directions from earthquake fault plane solutions in Western Norway collected by Bungum et al. (1991); b) Rose-diagram of $P$-axes from in-situ stress measurements in Norway (collected by Bungum et al., 1991).

(i.e. coast). This ridge push is associated with an elevation and with subsequent neotectonic effects resulting from intracratonic compressional stress regimes (Stephansson, 1988; Stephansson et al., 1988; Talbot and Slunga, 1989).

\subsection{Alpine continental tectonic influence}

The tectonic force from the Alps influenced nearby areas strongly. During the further propagation of the Alpine compression towards the $\mathrm{N}$ (in the direction of $c a . \mathrm{N} 155^{\circ} \mathrm{E}$, fig. $2 \mathrm{a}, \mathrm{b}$ ), it traversed the great Zechstein salt belt in Central and Northern Germany and in the Danish-Polish basin. The existence of a vast sheet of lowrigidity, low-friction semi-viscous salt would make it easier for the uppermost sedimentary sheet, above the salt, to yield by horizontal transport, thrusting and folding, and almost NW-SE faulting. During this process, movements of the uppermost crustal level must have been partly absorbed by plastic deformation of anhydrites as well as deformation of the uppermost sediments. Part of the movement transfer through the deeper-level crust took place along the NW$\mathrm{SW}$ ( $\mathrm{ca}$. N120 $\mathrm{E}$ ) trending lineament of the Sorgenfrei-Tornquist zone, and along the conjugate (NNE-SSW, $c a$. N25 E, trending) GotlandOrland and Skagerrak-Oslo zones as well as along the lenticular-shaped mega-shear system $\mathrm{W}$ of and conformable to the Protogine zone. As mentioned earlier, the Bohus granite belt is part of this system. Reactivation of the Swedish megalens fault zones with a strike-slip duplex model during Tertiary time has been suggested by Talbot and Slunga (1989).

The large fault-lineaments of the SorgenfreiTornquist-, Gotland-Orland- and SkagerrakOslo-zones trend almost identically to the joints of Bohuslän, and may belong to the same Alpine continental tectonic stress system. The dex- 
tral transpressional displacements along the NW striking Sorgenfrei-Tornquist fracture system (Bergström, 1984; Norling and Bergström, 1987; Wannäs and Flodén, 1994), and the sinistral movements along NNE striking faults (Berthelsen and Marker, 1986; Strömberg, 1981) in the Baltic Sea would fit into the Alpine tectonic influence-pattern. In the Bohus granite dikes which were suggested to be late Carboniferous and Permian age (Thorning and Abrahamsen, 1980) are cut by joints and joint systems. These joints being post-Permian features might have occurred during the Mesozoic as well as Cenozoic time. Brittle linear structures with particularly sharp and straight lines mapped in S Sweden are apparently the youngest among all sorts of lineaments, as suggested by Tirén and Beckholmen (1992). Therefore, the hypothesis of an Alpine age for the Bohus granite joint system and the large fracture zones is in agreement with many indications from the Alpine continental tectonic regime.

\subsection{Atlantic tectonic influence}

The extensional nature of Atlantic tectonics (Vogt and Tucholke, 1986; Tankard and Balkwill, 1989) has been recognized for decades of geological and geophysical investigations, mechanical simulations and paleomagnetic studies. In the late Cretaceous, volcanic activity started north of Scotland in an extended area roughly corresponding to the mid-Atlantic ridge. During the transition from Paleocene to Eocene, about $55 \mathrm{Ma}$ ago, the volcanic activity increased and very heavy basic outflows started to take place. According to the plate-tectonic model, an increased heat flow in the growing mid-Atlantic ridge in relation to that in the adjacent deep sea basins resulted in a ridge push towards the continental margins on either side (Artyushkov, 1973). According to the global wrench tectonic model (Storetvedt, 1997), the Atlantic ridge push originated from a transpressional regime due to a differential in-situ rotation of Europe versus North America. In either model, the Norwegian western coast was apparently influenced by the ridge push from the $\mathrm{W}$ (at latitudes $<62^{\circ} \mathrm{N}$ ) and NW (at latitudes $>62^{\circ} \mathrm{N}$ ), acting generally at right angles to the trend of the coast-line (fig. 2a,b): the principal stress trajectories generally tend to become normal to the trend of a discontinuity, because no shearing stresses can be transmitted across the latter. A principal stress state fitting the above models well has been determined not only by the present study of joints, lineaments and valley directions, but also by various more direct (in-situ and seismic) methods by several authors, as outlined above. Thus, the maximum principal stress direction in $S$ (latitudes $<62^{\circ} \mathrm{N}$ ) Norway would be E-W [and $\mathrm{NW}-\mathrm{SE}$ in $\mathrm{N}$ (latitudes $>62^{\circ} \mathrm{N}$ ) Norway] due to Atlantic.

\section{Conclusions}

The dominant and distinct joint systems in Bohuslän and the neighboring areas, as shown in the diagrams of the joint orientations and the evaluation data, provide the data for determining the stress states caused by the neotectonic movements. The Alpine tectonism leading to a NNW-SSE and/or NW-SE compressional stress regime is considered to have caused the N-S and E-W joints in Sweden area. The almost N-S and $\mathrm{E}-\mathrm{W}$ directed principal stresses in the southern areas of Norway (latitudes $<62^{\circ}$ ) are directly related to the Atlantic tectonic regime (ridgepush towards the coasts of Scandinavia, France, Portugal and North-Africa) and the ensuing neotectonic intracratonic stress regime: thus, there seems to be a fundamental tectonic dividing line along the Skagerrak continued by the Oslo graben. According Storetvedt (1997, p. 290) this dividing line can even be followed as far as the Rhine graben.

\section{REFERENCES}

ÅHÄLl., K.I. and J.S. DALY (1989): Age, tectonic setting and provenance of Östfold-Marstrand Belt Supracrusts: westward crustal growth of the Baltic shield at 1760 Ma., Precambrian Res., 45, 45-61.

ARTYushkov, E.V. (1973): Stresses in the lithosphere caused by crustal thickness inhomogeneities, J. Geol. Res., 78 (32), 7675-7708.

Asklund, B. (1947): Gatsten och kantsten, Sver: Geol. Unders. Ser. C, 479, pp. 187. 
Bergström, J. (1984): Symposium on Tornquist zone geology: summary of scientific presentations, Geol. Fören. Stockholm Förh., 106, 379-380.

Berthel.SEN, A. and M. MARKer (1986): 1.9-1.8 Ga old strike-slip megashear in the Baltic shield, and their plate tectonic implications, Tectonophysics, 128, 163-181.

Bungum, H., A.L. Alsaker and B. Hamsen (1991): Seismicity and seismotectonics of Norway and Nearly continental shelf areas, J. Geophys. Res., 96 (B2), 22492265.

CAPUTO, R. (1995): Evolution of orthogonal sets of coeval extension joints, Terra Nova, 7 (5), 479-490.

Dimroth, E. (1963): Fortschritte der Gefuegestatistik, $N$. Jahrl. Mineral. Monatsh. Stuttgart, 1963, I86-192.

ELIASSON, T. and H. SCHOBERG (1991): U-Pb dating of the post-kinematic Sveconorwegian (Grenvillian) Bohus granite, SW Sweden: evidence of restitic zircon, Precambrian Res., 51, 337-350.

FAlkum, T. and J.S. PETERsen (1980): The Sveconorwegian Orogenic belt, a case of late-Proterozoic plate-collision, Geol. Rundsch., 69 (3), 622-647.

FLODÉN, T. (1973): Notes on the bedrock of the Eastern Skagerrak with remarks on the Pleistocene deposits, Stockholm Contrib. Geol., 24 (5), 79-102.

GaAl, G. and R. Gorbatsciev (1987): An outline of the Precambrian evolution of the Baltic shield, Precambrian Res., 35, 15-52.

Gregersien, S., H. Korhonen and E.S. Husebye (1991): Fennoscandian dynamics,-present-day earthquake activity, Tectonophysics, 189, 333-344.

HANCOCK, P.L. and T. ENGELDER (1991): Neotectonic joints: reply, Geol. Soc: Am., Bull, 103, 432-433.

HAST, N. (1974): The state of stress in the upper part of the Earth's crust as determined by measurements of absolute rock stress, Naturwissenschaften, 61, 468-475.

KOHLBECK, F. and A.E. SCHEHEGGER (1977): On the theory of the evaluation of joint orientation measurements, Rock Mech., 9, 9-25.

Kohlbeck, F, and A.E. SCHEidegger (1985): The power of parametric orientation statistics in the Earth Sciences, Mitt. Österr. Geol. Ges., Wien, 78, 251-265.

Moнr, O. (1928): Abhandlungen aus dem Gebiete der technischen Mechanik. 3.Auflage (Wilh. Ernst and Sohn, Berlin), pp. 622.

Müller, B.M.L., M.L. Zoback, K. Fuchs, L. Mastin, S. GRegersen, N. Pavoni, O. Stephansson and C. LJUNGGREN (1992): Regional patterns of tectonic stress in Europe, J. Geophys. Res., 97, 11783-11803.

NORLING, E. and J. BERGSTRÖM (1987): Mesozoic and Cenozoic tectonic evolution of Scania, Southern Sweden, Tectonophysics, 137, 7-19.

PRICE, N.J. (1966): Fault and Joint Development in Brittle and Semi-Brittle Rock (Pergamon Press, Oxford), pp. 176.

RAMBERG, I.B. and B.T. LARSEN (1978): Tectonomagmatic evolution, Nor. Geol. Under, 337 (The Oslo Paleorift), $55-73$.

SCHEIDEGGER, A.E. (1978): The enigma of jointing, Riv. Ital. Geofis. Sci. Affini, 5, 1-4.
SCHEIDEGGER, A.E. (1991): Neotectonic joints: discussion, Geol. Soc. Am., Bull., 103, 432.

SCHEIDFGGER, A.E. (1993): Joints as neotectonic plate signatures, Tectonophysics, 219, 235-239.

SCHIIDEGGER, A.E. (1995): Geojoints and geostresses, in Mechanics of Jointed and Faulted Rock, Proc. 2nd Internat. Conf. on the Mechanics of Jointed and Faulted Rock, Balkema, Rotterdam, edited by H.P. ROSSMAMITH, $1-35$.

Shgill, P. and D.D. POllari) (1983a): Nucleation and growth of strike-slip faults in granite, J. Geophys. Res. 88 (B1), 555-568.

SFGall, P. and D.D. POLlARD (1983b): Joint formation in granite rock of the Sierra Nevada, Geol. Soc. Am., Bull., 94, 563-575.

SLungA, R. (1981): Fault mechanisms of Fennoscandian earthquakes and regional tectonic stresses, Geol. Fören. Stockholm Förh., 103 (1), 27-31.

Slunga, R., P. NORMAN and A.-C. Galns (1984): Baltic shield seismicity, the results of a regional network, Geophys. Res. Lett., 11 (12), 1247-1250.

STEPHANSSON, O. (1988): Ridge push and glacial rebound as rock stress generators in Fennoscandia, Bull. Geol. Inst. Univ. Uppsala, special issue N.S., 14, 39-48.

StePhansSON, O., C. LJUNGGREN and L.-O. DAHLSIRÖM (1988): Swedish stress data for the World Stress Map Project and geological implications of the data in FRSDB, in Workshop on Nordic Rock Stress Data, Trondheim, October 10, 1988, SINTEF Report.

Stephansson, O., C. LuUngGreN and L. Jing (1991): Stress measurements and tectonic implications for Fennoscandia, Tectonophysics, 189, 317-322.

Storiztvedt, K.M. (1997): Our Evolving Planet, Earth History in a New Perspective (Alma Mater Forlag AS, Bergen), pp. 456.

StoretVEdT, K.M. and A.E. SCHEIdEgGER (1992): Orthogonal joint systems in the Bergen area, Southwest Norway, and their regional significance, Phys. Earth Planet. Inter., 73, 255-263.

STRÖMBERG, A.G.B. (1981): The European Caledonides and the Tornquist Lineament, Geol. Fören. Stockholm Förh., 103 (2), 167-171.

Sturt, B.A., A. ThON (1978): Caledonides of Southern Norway, Geol. Surv. Can., Pap., 78-13, 39-47.

TALBOT, C. and R. SLunga (1989): Pattem of active shear in Fennoscandia, in Earthquakes at North-Allantic Passive Margins: Neotectonics and Postglacial Rebound, edited by S. GREGERSEN and P.W. BASHAM (Kluwer Acad. Publ. Dordrecht), 441-446.

TANKARD, A.J. and H.R. BALKWILL (1989): Extensional tectonics and stratigraphy of the North Atlantic margin, Am. Assoc. Petrol. Geol. Mem., 46, 111-129.

Thorning, L. and N. ABRAhAMSEN (1980): Paleomagnetism of Permian multiple intrusion dykes in Bohuslän, SW Sweden, Geophys. J. R. Astron. Soc., 60, 163-185.

TirÉN, S.A. and M. BECKHOLM (1992): Rock block map analysis of Southern Sweden, Geol. Fören. Stockholm För.h., 114, 253-269.

VogT, P.R. and B.E. Tucholke (Editors) (1986): The Western North Atlantic Region, Geological Society of America, Boulder, pp. 696. 
WANNÄS, K.O. and T. FLODÉN (1994): Tectonic framework of the Hanö Bay area, Southern Baltic Sea, Svensk Känbränslehantering $A B$, Tech. Rep., 94 (09), pp. 40. WATSON, G.S. (1970): Orientation statistics in the Earth sciences, Bull. Geol. Inst. Uppsala, N.S., 2 (9), 73-89.

WELIN, E. and R. GoRBATSCHEV (1978): Rb-Sr isotopic relations of a tonalitic intrusion on Tjörn Island, SW Swèden, Geol. Fören. Stockolm Förh., 98 (4), 374-376.

Welin, E., R. Gorbatschev and A.-M. KÄHR (1982): Zircon dating of polymeta-morphic rocks in Southwestern Sweden, Sver. Geol. Under., Ser. C, 797, Årsbok, 76 (10).

ZHENG, F. (1996): Tectonic development of the Bohus granite (SW Sweden) and its adjoining areas, Stockholm Contrib. Geol., 44, 1-208.

ZOBACK, M.L. (1992): First- and second-order patterns of stress in the lithosphere: The World Stress Map Project, J. Geophys. Res., 97, 11703-11728.

ZOBACK, M.L., S.P. NISHENKO, R.M. RICHARDSON and M.D. ZOBACK (1986): Mid-plate stress, deformation, and seismicity, in The Western North Atlantic Region, edited by P.R. VOGT and B.E. TUCHOLKE, Boulder, Geol. Soc. Am., 197-312.

(received May 25, 1999; accepted September 28, 1999) 